\title{
U.TURAN
}

\section{THE PRINCIPLES AND COMPONENTS OF BUSINESS MODELS FOR SUSTAINABILITY}

The article combines the key principles and components of business sustainability, highlights the specific features of the energy sector. Ukrainian small and medium-sized businesses have just begun to take their first tentative steps towards a completely different approach to creating and maintaining value, but this article concludes that there will be completely new perspectives for sustainable enterprise development along with new ways of creating and maintaining value.

This article provides a theoretically grounded as well as a realistic account of how business model development can be an important component in the overall transition to sustainable development, going beyond the pursuit of innovative technologies. For the Kharkiv-focused small and medium-sized companies, which were developed by the author and worked with, sustainable development groups were formed and the important order of the indicators of these groups was sent to the companies as a survey study. In addition, a mechanism by which SMEs can adopt the Energy 4.0 approach in line with the modernization and innovative structure of the energy sector and the energy targets of Ukraine has been presented to their organizations. The author proposed a Sustainable Development Association, where SMEs will supervise and consult all these digitalization and innovation processes in line with their sustainable development goals. This association has been planned as a joint structure for the development of existing SMEs in the entire energy sector.

As a result of the study, the basic components of the organizational mechanism were identified. The main elements are characterized and their content is revealed. It has been observed that the majority of the feedback received from the companies has a positive intention and adopts an energy 4.0 understanding. The presence of the relevant components of the mechanism in small and medium-sized businesses is revealed. With the growing understanding that innovative technologies alone are not enough to make sustainable growth a reality, the article focuses on the need to find and create radically new business models.

Keywords: sustainable business; digitalization; organizational structure; sustainable development; small and medium-sized enterprises

\section{У.ТУРАН}

\section{ПРИНЦИПИ ТА КОМПОНЕНТИ БІЗНЕС МОДЕЛЕЙ СТАЛОГО РОЗВИТКУ}

У статті об'єднані ключові принципи і складові стійкості бізнесу, висвітлено особливості енергетичного сектору. Робиться висновок про те, що з'являються нові перспективи для сталого розвитку підприємств поряд з новими способами створення і підтримки їх виробничої функції. У дослідженні наводиться теоретично обгрунтований, а також реалістичний погляд на необхідність розробки бізнес-моделі як важливої компоненти загального переходу до сталого розвитку, який стає ширшим ніж впровадження інноваційних технологій. Для українських малих і середніх підприємств (МСП), які досліджував автор, були сформовані групи сталого розвитку, і визначена послідовність показників цих груп. Підприємствам було запропоновано проаналізувати анкети і розглянути механізм взаємодії, за допомогою якого МСП могли б оцінити можливість застосування підходу «Еnergy 4.0». Автор запропонував створити необхідну структурну одиницю, а саме, Асоціацію сталого розвитку, в якій для МСП з'являється можливість контролювати і проводити консультації з процесів цифровізації та інновацій відповідно до цілей сталого розвитку. Ця асоціація була виділена як спільна структура для розвитку існуючих малих і середніх підприємств у всьому енергетичному секторі. В результаті дослідження були визначені основні компоненти організаційного механізму, охарактеризовано основні елементи та розкрито їх зміст. Було зазначено, що більшість відгуків, отриманих від МСП, мали позитивний характер і були засновані на розумінні та сприйнятті концепції «Energy 4.0». Визначено наявність відповідних складових механізму в малому і середньому бізнесі. У зв'язку з усвідомленням того, що застосування одних інноваційних технологій недостатньо для забезпечення сталого розвитку, в статті робиться акцент на необхідність пошуку і створення радикально нових бізнес-моделей.

Ключові слова: сталий бізнес; дігіталізація; організаційна структура; сталий розвиток; малі та середні підприємства

\section{У.ТУРАН \\ ПРИНЦИПЫ И КОМПОНЕНТЫ БИЗНЕС МОДЕЛЕЙ УСТОЙЧИВОГО РАЗВИТИЯ}

В статье объединены ключевые принципы и составляющие устойчивости бизнеса, освещены особенности энергетического сектора. Делается вывод о том, что возникают новые перспективы для устойчивого развития предприятий наряду с новыми способами создания и поддержания их производственной функции. В исследовании приводится теоретически обоснованный, а также реалистичный взгляд на необходимость разработки бизнес-модели как важной компоненты общего перехода к устойчивому развитию, выходящему за рамки внедрения инновационных технологий. Для украинских малых и средних предприятий (МСП), которые исследовал автор, были сформированы группы устойчивого развития, и определена последовательность показателей этих групп. Предприятиям было предложено проанализировать анкеты и рассмотреть механизм взаимодействия, с помощью которого МСП могли оценить возможность применения подхода «Еnегgy 4.0». Автор предложил создать необходимую структурную единицу, а именно, Ассоциацию устойчивого развития, в которой для МСП появляется возможность контролировать и консультироваться по процессам цифровизации и инноваций в соответствии с целями устойчивого развития. Эта ассоциация была выделена как совместная структура для развития существующих малых и средних предприятий во всем энергетическом секторе. В результате исследования были определены основные компоненты организационного механизма, охарактеризованы основные элементы и раскрыто их содержание. Было указано, что большинство отзывов, полученных от МСП, имели позитивное намерение и были основаны на понимании концепции «Energy 4.0». Определено наличие соответствующих составляющих механизма в малом и среднем бизнесе. В связи с осознанием того, что применения одних инновационных технологий недостаточно для обеспечения устойчивого развития, в статье делается акцент на необходимость поиска и создания радикально новых бизнес-моделей.

Ключевые слова: устойчивый бизнес; дигитализация; организационная структура; устойчивое развитие; малые и средние предприятия

Introduction. Most governments now recognize the impact of business on society and the environment. The fundamental role of sustainable business is to benefit society through value-added products and services. But under the influence of what factors the business begins to change. The pressure on the business community means that business leaders are well aware of their corporate social responsibility. They recognize that their actions must 
be directed towards greener businesses. The theory of economic mechanism design has contributed essentially to this theory, driven by Eric Maskin in the literature, by Leonid Hurwicz and Roger Myerson, giving a precise and careful approach to deal with crucial problems in economics. Mechanism design theory covers the design of rules and techniques for institutional arrangements, economic actions, and collective decision making. This theory gives a comprehension of the working of numerous foundations, from basic guidelines of trade to political developments.

The study, which is viewed as the basic of mechanism design theory, is seen in Leonid Hurwicz's Mathematical Methods in Social Sciences in 1960. In time, this theory was created by Maskin and Myerson. Along with the Decisions and Organizations published by Hurwicz in 1972, "incentive compatibility" to the literature and "revelation principle" and "implementation theory" during the 1970s were remembered for the theory of economic mechanism design [1][2][3]. The reputation of organization and an economic mechanism is recognized for numerous sectors, businesses, and policymakers. It is of excessive significance in meeting both economic and social essentials, the requests of industries, and establishing regular and precise systems. All these requirements interconnect with the reality of developing the theoretical and methodological principles of the appropriate mechanisms of act. Harmonisation of the interaction of organizational and economic components creates appropriate effective mechanisms that support economic development and issues. In solving economic problems, modern circumstances of socio-economic developments and acceleration of processes need new approaches. All these progresses will support and encourage the development of the theoretical and methodological principles of the organizational and economic mechanism. According to Nobel laureate economist Erik Maskin, mechanism design theory reverses the business; He highlighted that he primary put forward the desired outcome and then worked on the design of the institutions that will produce these results. This theme is a real vital point of view for businesses. They have to take their place in the sector by setting the targets. According to Maskin in 2008 [1], he stressed that mechanism design theories could be used for agreements among countries to reduce carbon emissions connected to global warming or to overcome economic crises. Many historical actions took place after 2007, for instance the 2008 world economic crisis, the Paris Climate Treaty to battle climate change or the Sustainable Development Goals prepared by the United Nations. All of these important events have their mechanism and goal. In the framework that will emerge at the end of this thesis, it will be stated how important the indicators owned by SDGs are for companies and an alternative perspective will be presented to SMEs according to the economic mechanism.

Once the concept of organization and an economic mechanism is examined, it is essential to first assume the structures of the enterprises since there are small and medium enterprises. These concepts are examined under 2 main titles, in other words, only as an organization and economic mechanism, the key functions of the organisation, which are essential and useful in business management, are as follows: planning, organization, referral, and administration, coordination and supervision.

The purpose of the article is to study the theoretical provisions, substantiation of methodological approaches and practical recommendations for the formation of organizational - economic mechanism of enterprises to ensure sustainable development.

The object of research is modern small and mediumsized enterprises.

A broader considerate of what makes a business sustainable and what are the key features of sustainable business practices is an imperative primary step to understanding what drives a business to change.

According to Erik Maskin in 2011 [2], Nash equilibrium claims that economics and political science used in mechanism design is the utmost optimal and least challenging solution. He states that the most approving conditions for mechanisms are provided with this equilibrium in strategic environments. Mechanism design includes the design of corporate regulations, guidelines, and measures for collective decision making. The main issue is how to get private and scattered information properly to accomplish private and social aims. The data contributes meaningfully to the understanding of the optimal distribution mechanism or the characteristics of the institution, with an emphasis on individuals' incentives and private information. From this viewpoint, SMEs are recommended to make use of data in their companies. Long term describes the real difference among being clean (environmentally friendly) and being sustainable. Any business must provide facilities or products that are environmentally friendly.

When SMEs emphasis on energy transmission and production, they have to set a direction for them under three main headlines for energy supply security that are national, regional, and local, respectively. The projects to be produced for National would focus on reliable transmission, development of transmission systems, and uninterrupted infrastructure. With the assistance of municipalities for the Regional, it is to inform and inspire businesses and consumers on renewable energy production and consumption. According to Dergachova [4] et al., in 2018, the industrial potential of Ukraine prevents regular economic growth because of geopolitical conflicts. With a new manufacturing restoration and political vision, all progresses can be made possible, especially with cluster systems to be generated in the field of energy, they can solve regional problems and be a solution with an original national economic growth modelling [4].

Methodology. The empirical studies were carried out in February-June 2020. As part of the study, it was conducted a survey of enterprises using semi-structured questionnaires. The sample of the surveyed enterprises was clearly formed. The main issues that were considered during the survey of enterprises were questions related to the definition, in accordance with certain innovation groups, indicators according to their degree of significance or the possibility of their acceptability for enterprises.

Research has shown that businesses are looking for an equilibrium between cost and reward. However, are they willing to view reward as a multidimensional concept in 
which levels of sustainability coincide with monetary reward?

The baseline list of enterprises was obtained from the statistical office or compiled with the help of the relevant associations. It should be noted that there are some difficulties in obtaining responses from enterprises. Most of the questionnaires were completed via email and telephone. The format of the interview was previously discussed. The share of responses from enterprises was $66.7 \%$.

Limitations of data collection should be noted. First, the data used were subjective responses. And therefore, there is a double error of own answers and own choice.

Development of practical recommendations of strategy for SMEs. For a business to be sustainable, its approach must be strategically planned. The principles of sustainability must be combined into every business decision. In other words, to achieve sustainable business status, the strategy must be to develop highly skilled and capable employees using cultural, structural and personnel methods.

It is the main issue that Ukrainian SMEs should focus on. According to the author's suggestion to SMEs, companies must turn to digitalization solutions in order to make their sustainable development realistic and to exist in the future energy sector. By providing digitalization only with modernization and innovation, their adoption of the Energy 4.0 approach will make a great contribution to the sustainable development goals. The points to focus on with Energy 4.0 should be concepts such as technological revolution, big data analysis, smart systems, software applications, and conscious consumption. When the suggestions mentioned in the IEA's Digitalization report in 2017 [6] is studied, some of the notable themes are given as examples; Not to think of smart grids just like plug and play, to be controlled digitally, to strengthen infrastructures with simulations and modelling, to speed up the security of data science and digitalization, to plan energy management correctly and to attention on the integration of renewable energy, to diminish housing consumption with the improvement of home technologies, techno-parks, and incubation centres are among the topics discussed in the technology platform [5].

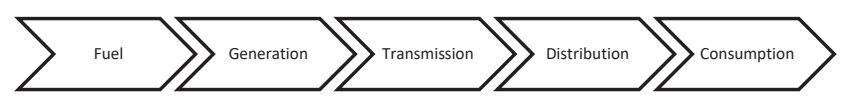

\section{Figure 1 - Classical Energy Flow}

In addition to all these, in Ukraine, instead of the classical energy flow shown in figure 1, the model is shown in figure $\mathbf{2}$, the digitalization model should be applied for Energy 4.0 mentality for future.

SMEs are measured as the most precise step by getting support from funds with the projects they will develop, for modernizing the infrastructures, increasing the efficiency of the houses, solving the difficulties of the system with the Energy 4.0 understanding with the resolutions that decrease the energy intensity of the manufacturing and then going into production. The reforms and investments that will cover the way for the country's energy sector and allow the integration of the European Union into the electricity grid concern all SMEs.

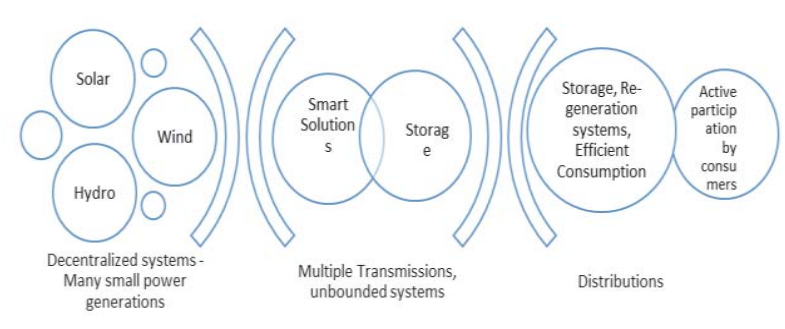

Figure 2 - Digital Energy Flow

The steps to be taken in these regions will be of extreme standing in future development. Also, policies are noteworthy to ensure the education of households, municipalities to actively increase awareness of citizens and to sell the surplus energy produced by households to the system over time, to take a dynamic role. With digitalization, decreasing costs over time concerns all SMEs. The resolve of old technologies, the change of systems that rise environmental pollution with high energy efficiency options, robotic aids, and the overview of Nanotechnologies into the system are the fundamentals that will bring the energy sector forward. A transition ought to be made to a policy set that uses energy efficiently, supplies it from national and renewable sources, and domestic equipment. Instead of establishing numerous new electricity facilities, which is the first way that comes to mind in meeting the growing electricity needs; policies and practices should be applied to manage the demand, to use energy extra efficiently, and to reduce the need for new facilities with the savings provided. Furthermore, energy efficiency is of greatest position in all these phases. For example, SMEs should be able to improve co-operative projects with municipalities, educate citizens on energy efficiency, give details on electricity consumption of small household appliances in daily life, and offer information on high-efficiency utilizations. As a result, with the assistance of technology, awareness that consumes less energy is increased. Lastly, the author has reached the following conclusion in his research. In the whole sustainable development process of the SMEs, an association should control and guide SMEs. This association should be on a mission to develop SMEs in line with sustainable development goals and to bring them to a more innovative structure.

\section{Conclusions.}

1. According to the research of the latest approaches, as a result of multifactor analysis, indicators were designated on which companies should attention and use them in the data analysis sector, taking into account the areas of possible reserves for their development. After creating integrated indicators for each group, they were placed in one chronological sequence. When studying the macro-indicators of Ukrainian enterprises on the base of trend analysis by comparing 4 innovative integrated groups and studying the peculiarities of the micro-environment of 
enterprises, an organizational and economic mechanism was proposed to help identify, first of all, bottlenecks.

When the general results were evaluated, the mechanism created by the multifactorial analysis of the data prepared by statistical methods by the author and presented to the SMEs in the Kharkiv-focused energy field with the contribution of the literature review was evaluated. The mechanism steps in the proposed Energy 4.0 path have been taken apart from one company and it has come to the conclusion that it will contribute to the future energy sector and evaluate SMEs on the path to sustainable development.

2. Empirical research has shown that the main lever for economic transformation in Ukraine is small and medium-sized businesses, which, compared to European cases, manner projects and study focused on modernization and innovation using the "Energy 4.0" approach. It was noted that the utmost significant issue to focus on in energy production is the solution and modernization of infrastructure problems in transmission systems. At the same time, solving structural problems for production is becoming a highest urgency to focus on. For instance, challenges such as avoiding the loss of energy in industrial structures, aware consumption, and preventing extreme greenhouse gas emissions from industry are becoming both opportunities and a focus for SMEs. If the projects and solutions to be established by SMEs in their activities become a practice with the funding of international funds, integration into European markets for Ukraine can be considerably accelerated. It is the indicators recognised in the study that will allow more flexible reaction and operation of the essential changes to the organizational structure.

3. A mutual feature of all targets for sustainable enterprise development is a flexible modern structure, production of high value-added goods and innovative progresses, creation of a reliable, environmentally friendly structure, development of energy efficiency-oriented infrastructure units and decrease of greenhouse gas emissions.

4. The motivation for businesses to become sustainable is the emphasis on the fact that they pay gradually attention to the human capital needed to develop and produce products and services. Various businesses have been beginning to realize that sustainable working practices are beneficial for stakeholder relationships, they shape trust among consumers and value people as a vital resource for businesses.

5. The general conclusion is that the Ukrainian energy sector essential to meet the modern challenges in the global world. Under this approach, the reforms established and decisions made allow to develop the renewable energy sector in the country. It is believed that the digitization of the energy sector, the introduction of new structures with an understanding of Energy 4.0 will directly contribute to the goals of the country's integration process into the EU. This integration goal will be with the contribution of SMEs. Therefore, by monitoring all objectives of the sustainable development association for the proposed SMEs, they will be able to both develop SMEs in the energy sector and develop their own sustainable development. At this point, it is necessary for SMEs to implement consulting services that should improve the skills of entrepreneurs, namely in the benefits of using clean and sustainable energy, which in the future may be their key competitive advantage.

\section{References}

1.

Maskin, E., 2008. Mechanism Design: How to Implement Social Goals. American Economic Review, 98(3), pp.567-576.

2. Maskin, E., 2011. Commentary: Nash equilibrium and mechanism design. Games and Economic Behaviour, 71(1), pp.9-11.

3. Hurwicz, L., 1973. The Design of Mechanisms for Resource Allocation. The American Economic Review, 63(2), 1-30.

4. Dergachova, V., Pysar, N., Kyvliuk, O. and Svyrydenko, D., 2018. Strategies for development of Ukrainian energy market under conditions of geopolitical challenges. Naukovyi Visnyk Natsionalnoho Hirnychoho Universytetu, (5), pp.148-154.

5. Savchenko, O., \& Turan, U. (2019). Research of the Impact of the Energy Management Condition on the Sustainable Development of the European Countries. Business Navigator: International University of Business and Law, Volume 56 (6.1), pp.222-229.

6. IEA, 2017. Digitalization and Energy - Analysis - IEA. [online] Available at: <https://www.iea.org/reports/digitalisation-andenergy> [Accessed 18 June 2020].

Received 21.07.2020

Відомості про авторів / Сведения об авторах / About the Authors

Туран Угур (Туран Угур, Turan Ugur) - аспирант каф. менеджменту інноваційного підприємництва та міжнародних економічних відносин Національний технічний університет «Харківський політехнічний інститут»; ORCID: 0000-0003-21685232 e-mail uturan55@gmail.com 